\title{
Profesionalisme Pendidik Anak Usia Dini
}

\author{
Martha Christianti \\ marthachristianti@yahoo.com \\ PGPAUD FIP Universitas Negeri Yogyakarta
}

\begin{abstract}
Abstrak
Pendidikan anak usia dini merupakan awal dari pendidikan yang lebih tinggi dan menjadi kunci dalam memperbaiki kualitas bangsa. Untuk mendapatkan hasil pembentukan anak yang berkualitas salah satunya didukung oleh pendidik yang profesional. Pendidik anak usia dini yang profesional memiliki ciri yaitu memiliki landasan keilmuan yang kuat tentang perkembangan anak dan belajar efektif, bersikap optimis dan memiliki pendekatan "aku bisa", hangat dan memiliki empati, spontanitas dan fleksibel, memiliki keahlian dalam melakukan refleksi dan analisis, memiliki kemampuan untuk berkomuniksasi dengan banyak orang, memiliki kemampuan memimpin, bermain penuh dan mampu menciptakan kegiatan belajar yang menyenangkan, memiliki imajinasi dan kreativitas yang tinggi, mampu merancang program dan melaksanakan pembelajaran yang mengacu pada analisis kebutuhan anak, dan kemampuan untuk secara terus menerus mendokumentasikan serta melakukan penilaian pada perkembangan pada anak.
\end{abstract}

Kata kunci: Profesionalisme, Anak Usia Dini

\begin{abstract}
Early aged children education is the beginning of higher education levels and becomes the key to make a betterment of the nation's quality. To achieve the result of children with high quality, among others, it should be supported by professional educators. Professional educators have some characteristics which are having strong scientific backgrounds on children development and effective learning, being optimistic and having the approach of "I can", being warm and empathetic, being spontaneous and flexible, being skilful in doing reflection and analysis, having good communication ability with others, having the ability of leadership, being able to play and create fun learning activities, having high imagination and creativity, being able to plan and execute learning activity that refers to the children's needs analysis, and being able to continuously record the documentation and do the evaluation of children's development.
\end{abstract}

Keywords: professionalism, early aged children

Pendahuluan
J umlah pendidik anak usia dini di Indonesia semakin meningkat. Pening- 
katan tersebut terjadi seiring dengan banyaknya jumlah anak yang harus dilayani (Direktorat PAUD, 2011). Namun kuantitas pendidik tersebut tidak pula diikuti oleh kualitas (kompetensi) pendidik anak usia dini. Pernyataan ini disampaikan oleh Kasi PAUD Formal Subdit PTK PAUD Direktorat PTK PAUDNI Kemen-dikbud Alhidayati Aziz (Anggun Puspita, 2012). Berdasarkan data yang diperoleh sejumlah 87,3 persen guru PAUD tidak memenuhi standar kompetensi. Standar kompetensi yang dimaksudkan yaitu dari standar kualifikasi akademik dan empat kompetensi yang harus dimiliki seorang guru PAUD yaitu kompetensi pedagogik, profesional, sosial dan kepribadian. Hal ini terjadi karena pendidik anak usia dini berasal dari latar belakang pendidikan yang berbeda, pendidik memiliki keterbatasan dalam mengakses program pengembangan diri, dan keterbatasan dukungan finansial (Redaksi, 2012). Rendahnya standar kompetensi pendidik PAUD terlihat dari kualifikasi akademik pendidik. Salah satu kendala dari rendahnya kualitas guru tersebut karena rata-rata guru PAUD bukan dari program studi atau jurusan PAUD (Anggun Puspita, 2012). Berdasarkan data yang diperoleh sejumlah 14 persen pendidik PAUD berpendidikan sarjana namun selebihnya berlatar belakang pendidikan SMA, dan D2 bahkan ada pula yang hanya berdasarkaan pengala-man (Rini, 2012).

Slamet Suyanto mengatakan bahwa pendidik PAUD hendaknya profesional (2005). Pendidik PAUD harus memiliki sertifikat sebagai pendidik PAUD agar dapat disebut sebagai profesional (Suara Merdeka, 2012). Hal ini mengingat penelitian-penelitian yang mengatakan bahwa masa dini adalah sebagai peletak dasar untuk pendidikan selanjutnya. Selain itu, masa dini merupakan masa emas perkembangan otak manusia. Untuk itu, perlu pendidik PAUD yang memahami peluang pemaksimalan tersebut sejak usia dini. Perlu ada upaya untuk meningkatkan kualitas layanan pendidikan untuk anak usia dini dengan cara meningkatkan kualitas para pendidik anak usia dini (Ahmad Rizali, dkk, 2009). Permasalahan ini kemudian menjadi tantangan bagi kita semua bahwa penting untuk meningkatkan tenaga pendidik yang berkualitas sehingga memiliki kompetensi untuk menjadi pendidik PAUD.

\section{Pendidikan Anak Usia Dini}

Anak usia dini didefinisikan oleh the National Association for the Education of Young Children (NAEYC) adalah anak yang berusia 0 sampai 8 tahun (Brewer, Jo Ann, 2007). Sedangkan menurut UU No. 20 Tahun 2003 mengatakan bahwa anak usia dini adalah anak yang berusia 0 sampai dengan 6 tahun. Berdasarkan pada UU tersebut pula anak usia dini dibina dalam jalur pendidikan formal, nonformal dan informal (Direktorat PAUD, TT). Jalur formal berbentuk Taman Kanak-kanak (TK)/Raudhatul Atfal (RA) dan bentuk lain yang sederajat. Sedangkan jalur pendidikan non formal berbentuk Taman Penitipan Anak (TPA) dan bentuk lain yang sederajat; Kelompok Bermain (KB) dan bentuk lain yang sederajat; Satuan PAUD Sejenis (SPS). Jalur informal adalah pendidikan yang diberikan orang tua dan masyarakat baik secara langsung atau tidak langsung kepada anak. Dari dua pengertian di atas terdapat perbedaan rentang usia yang disebut sebagai anak usia dini. Brewer mengatakan bahwa usia di atas usia 6 tahun sampai dengan 8 tahun masih masuk dalam rentang anak usia dini. Hal ini karena terkait dengan masa keemasan yang masih potensial terjadi pada usia tersebut. Penelitian menemukan 
bahwa otak manusia berkembang 50 persen pada tahun pertama kehidupan. Kemudian berkembang 30 persen sampai usia 8 tahun. Perkembangan otak tersebut terjadi sangat pesat pada usia dini sebanyak 80 persen otak manusia (H.E Mulyasa, 2012). Di Indonesia potensi tersebut diakui sebagai masa keemasan pula namun dari segi pengelompokkan usia secara birokrasi usia tersebut masuk dalam Sekolah Dasar (SD) kelas awal. Pada usia tersebut peluang untuk mengembangkan kemampuan dasar untuk hidup dimasa yang akan datang masih potensial untuk dimaksimalkan. Oleh karena itu, pendidikan awal di sekolah dasar sama pentingnya dengan pendidikan anak usia dini.

Pada usia dini, anak memiliki kemampuan yang luar biasa untuk menyerap segala sesuatu yang ada di sekitarnya. Pendidikan anak usia dini merupakan bentuk respon dari penelitian tentang masa keemasan pada usia tersebut. Hal ini sesuai dengan definisi pendidikan anak usia dini berdasarkan UU no.20 Tahun 2003 yang mengatakan bahwa PAUD adalah suatu upaya pembinaan yang ditujukan kepada anak sejak lahir sampai usia enam tahun yang dilakukan melalui pemberian rangsangan pendidikan untuk membantu pertumbuhan dan perkembangan jasmani dan rohani agar anak memiliki kesiapan dalam memasuki pendidikan lebih lanjut (Direktorat PAUD, TT).

Selain itu pendidikan anak usia dini menjadi sangat penting pula karena pendidikan awal dapat mengembang-kan pemikiran anak terhadap sekolah. Anak menyukai atau tidak tergantung pada awal pendidikannya. "school is exciting-/challengi$\mathrm{ng} /$ fun, and i am a good learner or school is boring/difficult/paintful, and i can't learn" (Kostelnik, Marjorie. J, 2007; 2). J adi ketika anak memperoleh pengala-man yang menyenangkan 114 pada pendidi-kan usia dini maka anak akan memiliki presepsi yang positif pula terhadap sekolah. Pengalaman menyenangkan tersebut harus dibangun dan diusaha-kan oleh guru. Hal ini menjadi sebuah bentuk tanggung jawab sebagai pendidik PAUD. Untuk menciptakan kegiatan belajar yang menyenangkan, pendidik harus mengetahui minat dan kebutuhan anak, mengetahui tahapan perkembangan anak dan bagaimana anak belajar. Kostelnik menjabarkan bagaimana perkembangan anak dan bagaimana anak belajar yaitu anak berkembang secara holistik, anak berkembang mengikuti waktu yang sama, proses perkembangan anak berbeda-beda pada setiap anak, anak adalah pebelajar aktif, belajar anak dipengaruhi kematangan, belajar anak dipengaruhi lingkungan, gaya belajar setiap anak berbeda, anak belajar melalui kombinasi pengalaman fisik, interaksi sosial dan refleksi, dan anak belajar melalui bermain (Kostelnik, Marjorie J , et all, 2007). Pemahaman terhadap pengetahuan ini diharapkan dapat menciptakan kegiatan bermain dan belajar yang menarik dan menyenangkan.

\section{Profesionalisme Pendidik Anak Usia Dini}

Pentingnya PAUD menuntut pendidik PAUD untuk menjadi profesional. Slamet Suyanto mengatakan bahwa profesional berarti bekerja sesuai prosedur, mengikuti etika profesi dan ilmu PAUD, serta tidak melakukan kesalahan (2005). Pendapat ini diperjelas oleh Driscoll, Amy dan Nagel, Nancy G bahwa "a profesional is someone who is educated, knowledgeable, dedicated to her profession, committed to completion of a specialized course of study, and in possesion of a knowladge base essential to her specialty area (2005; 415). Keharusan pendidik PAUD untuk 
masuk dalam golongan pekerjaan yang profesional telah dicanangkan dalam UU no. 20 Tahun 2003. Dalam UU tersebut disebutkan bahwa pendidik anak usia dini adalah profesional yang bertugas merencanakan, melaksanakan proses pembelajaran dan menilai hasil pembelajaran, serta melakukan pembimbingan, pengasuha dan perlindungan kepada anak didik (Direktorat PAUD, TT). Pendidik PAUD pada jalur pendidikan formal terdiri atas guru dan guru pendamping; sedangkan pendidik PAUD pada jalur pendidikan nonformal terdiri atas guru, guru pendamping dan pengasuh. Pendidik anak usia dini selayaknya masuk dalam standar yang telah ditentukan oleh pemerintah. Kualifikasi akademik guru yaitu memiliki ijazah D-II PGTK dari perguruan tinggi yang terakreditasi atau ijazah minimal sekolah menengah atas (SMA) atau sederajat dan memiliki sertifikat pelatihan/ pendidikan/kursus PAUD yang terakreditasi.

Kompetensi pendidik PAUD dikembangkan dalam konteks kebijakan sesuai dengan standar pendidik anak usia dini berdasarkan peraturan menteri pendidikan nasional RI no. 58 Tahun 2009. Berdasarkan acuan tersebut pendidik harus memiliki empat kompetensi yaitu kompetensi kepribadian, kompetensi profesional, kompetensi pedagogik, dan kompetensi sosial. Berikut ini dijabarkan masingmasing kompetensi tersebut.

Kompetensi kepribadian yaitu kemampuan untuk bersikap dan berperilaku sesuai dengan kebutuhan psikologis anak, sesuai dengan norma, agama, budaya dan keyakinan anak, dan menampilkan diri sebagai pribadi yang berbudi pekerti luhur. Pendidik yang memiliki kompetensi kepribadian ditunjukkan melalui tingkah laku yaitu menyayangi anak secara tulus, berperilaku sabar, tenang, ceria, serta penuh perhatian; memiliki kepekaan, responsif dan humoris terhadap perilaku anak; menampilkan diri sebagai pribadi yang dewasa, arif dan bijaksana; berpenampilan bersih, sehat dan rapi; berperilaku sopan santun, menghargai dan melindungi anak; menghargai anak tanpa membedakan keyakinan yang dianut, suku, budaya dan jender; bersikap sesuai dengan norma agama yang dianut, hukum dan norma sosial yang berlaku dalam masyarakat; mengembangkan sikap anak didik untuk menghargai agama dan budaya lain; berperilaku jujur; bertanggung jawab terhadap tugas; berperilaku sebagai teladan.

Kompetensi profesional terkait dengan kemampuan untuk memahami tahapan perkembangan anak, pertumbuhan dan perkembangan anak, kemampuan untuk memberikan rangsangan pendidikan, pengasuhan dan perlindungan, dan kemampuan untuk membangun kerjasama dengan orang tua dalam pendidikan, pengasuhan dan perlindungan anak. Kompetensi ini ditunjukkan dalam bentuk kemampuan pendidik dalam memahami kesinambungan tingkat perkembangan anak usia 0-6 tahun; memahami standar tingkat pencapaian perkembangan anak; memahami bahwa setiap anak mempunyai tingkat kecepatan pencapaian perkembangan yang berbeda; memahami faktor penghambat dan pendukung tingkat pencapaian perkembangan; memahami aspek-aspek perkembangan; memahami faktor yang menghambat dan mendukung aspek perkembangan tersebut; memahami tanda-tanda kelainan pada setiap aspek perkembangan anak; mengenal kebutuhan gizi anak sesuai dengan usia; memahami cara memantau nutrisi, kesehatan dan keselamatan anak; mengetahui pola asuh yang sesuai dengan usia anak; mengenal keunikan anak; mengenal cara-cara pemberian rangsangan dalam pendidikan, pengasuhan, dan perlindungan secara umum; memiliki keterampilan dalam 
melakukan pemberian rangsangan pada setiap aspek perkembangan; mengenal faktor-faktor pengasuhan anak; mengkomunikasikan program lembaga kepada orang tua; meningkatkan keterlibatan orang tua dalam program di lembaga; meningkatkan kesinambungan program lembaga dengan lingkungan keluarga.

Kompetensi pedagogik adalah kemampuan yang terkait dengan merencanakan kegiatan program pendidikan, pengasuhan dan perlindungan, melaksanakan proses dan melaksanakan penilaian terhadap proses dan hasil pendidikan, pengasuhan, dan perlindungan. Kemampuan ini ditunjukkan dalam bentuk kemampuan pendidik dalam menyusun rencana kegiatan tahunan, semesteran, bulanan, mingguan dan harian; menetapkan kegiatan bermain yang mendukung tingkat pencapaian perkembangan anak; merencanakan kegiatan yang disusun berdasarkan kelompok usia; mengelola kegiatan sesuai dengan rencana yang disusun berdasarkan kelompok usia; menggunakan metode pembelajaran melalui bermain sesuai dengan karakteristik anak; memilih dan menggunakan media yang sesuai dengan kegiatan dan kondisi anak; memberikan motivasi untuk meningkatkan keterlibatan anak dalam kegiatan; dan memberikan bimbingan sesuai dengan kebutuhan anak; memilih cara-cara penilaian yang sesuai dengan tujuan yang akan dicapai; melakukan kegiatan penilaian sesuai dengan cara-cara yang telah ditetapkan; mengelolah hasil penilaian; menggunakan hasil penilaian untuk berbagai kepentingan pendidikan; mendokumentasikan hasil-hasil penilaian.

Kompetensi sosial adalah kemampuan guru dalam beradaptasi dengan lingkungan dan berkomunikasi secara efektif dengan anak didik, dan orang tua. Kompetensi ini ditunjukkan 116 melalui kemampuan pendidik dalam menyesuaikan diri dengan teman sejawat; menaati aturan lembaga; menyesuaikan diri dengan masyarakat sekitar; akomodatif terhadap anak didik, orang tua, teman sejawat dari berbagai latar belakang budaya dan sosial ekonomi; berkomunikasi secara empatik dengan orang tua peserta didik; dan berkomunikasi secara efektif dengan anak didik, baik secara fisik, verbal dan nonverbal.

Penjabaran kompetensi tersebut dari sisi kebijakan jika diterapkan maka akan menghasilkan pendidik anak usia dini yang ideal atau profesional. Untuk menuju pada pemaksimalan kompetensi tersebut pemerintah melakukan berbagai usaha diantaranya melalui pemberian pelatihan-pelatihan. Usaha tersebut dilakukan untuk meningkatkan kompetensi pedagogik dan kompetensi profesional. Pengembangan kompetensi kepribadian dan sosial harus dikembangkan oleh pendidik sendiri melalui interaksi guru dengan anak, orang tua, atau dengan sesama pendidik.

Kompetensi tersebut hendaknya didukung dengan karakteristik dasar yang harus dimiliki oleh seorang pendidik PAUD. Edgington menuliskan beberapa karakteristik penting yang harus dimiliki oleh pendidik anak usia dini. Karakteristik tersebut yaitu memiliki landasan keilmuan yang kuat tentang perkembangan anak dan belajar efektif; bersikap optimis dan memiliki pendekatan "aku bisa"; hangat dan memiliki empati; spontanitas dan fleksibel; memiliki keahlian dalam melakukan refleksi dan analisis; memiliki kemampuan untuk berkomuniksasi dengan banyak orang; mampu memimpin; bermain penuh dan mampu menciptakan kegiatan belajar yang menyenangkan; memiliki imajinasi dan kreativitas yang tinggi; mampu merancang program dan melaksanakan pembelajaran yang 
mengacu pada analisis kebutuhan anak; dan kemampuan untuk secara terus menerus mendokumentasikan serta melakukan penilaian pada perkembangan pada anak (Edgington, Margaret, 2004).

Karakteristik memiliki landasan keilmuan yang kuat tentang perkembangan anak dan belajar efektif. Karakteristik ini hanya dapat diperoleh melalui latihan, membaca, dan mengamati. Pendidik mengetahui perkembangan anak dari membaca, kemudian mengamati perkembangan tersebut secara nyata. Dengan mengamati anak, pendidik mengetahui kebutuhan anak. Hasil dari pengamatan tersebut kemudian digunakan untuk membuat program yang relevan dengan kurikulum. Pendidik berlatih untuk mengembangkan program yang sesuai dengan kebutuhan anak dan sesuai dengan kurikulum.

Bersikap optimis dan memiliki pendekatan "aku bisa”. Pendidik anak usia dini berperan menjadi model untuk anak didiknya. Jika pendidik bersikap negatif dan tidak memiliki antusias, maka sikap tersebut dapat mempengaruhi energi optimis seorang anak. Artinya bahwa pendidik anak usia dini harus senantiasa memiliki sikap positif dan optimis walaupun mengalami banyak tantangan. "a pessimist sees the difficulty in every opportunity; an optimist sees the opportunity in every difficulty" (Edgington, Margaret, 2004; 8). Peran pendidik sebagai motivator tidak hanya terlihat dari bagaimana pendidik memberi dukungan kepada anak untuk mengambil bagian dalam kegiatan bermain namun diri pendidik itu sendiri menjadi inspirasi bagi anak untuk memiliki inisiatif, berkreasi, dan beraktivitas.

Hangat dan memiliki empati. Perlu menjadi penegasan bahwa untuk menjadi pendidik bagi anak usia dini syarat utama adalah pendidik harus menyukai anak-anak. Kesukaan terhadap anak-anak dan dunianya membuat pendidik lebih mudah melakukan pendekatan, menjadi guru yang hangat, mampu secara konsisten untuk merespon anak dan orang tua dari berbagai kalangan dengan bersahabat, memiliki pola pikir inklusi, tidak membedakan, dan mampu melihat anak dan orang tua dari sisi positif. Untuk mencapai hal tersebut, pendidik harus mengembangkan ke-mampuan untuk berkomunikasi deng-an banyak orang. Selain itu, pendidik perlu memiliki hubungan yang kuat dengan orang tua sebagai teman dalam satu tim untuk mendidik anak, walaupun orang tua memiliki latar budaya yang berbeda.

Spontanitas dan fleksibel. Pendidik anak usia dini harus memiliki spontanitas dan fleksibilitas yang tinggi. Hal ini terjadi karena anak tidak dapat diprediksi, anak sibuk bermain dalam dunianya dan penyelesaian yang dilakukan setiap anak tidak selalu sama dengan apa yang dilakukan orang dewasa. Pendidik anak usia dini harus fleksibel dan mengikuti arahan anak, merespon dengan antusias pada kegiatan yang spontan dan memandang kegiatan tersebut sebagai peluang untuk belajar secara utuh.

Pendidik anak usia dini harus memiliki keahlian dalam melakukan refleksi dan menganalisis kegiatan mengajarnya. Karakteristik ini perlu dikembangkan untuk meningkatkan kemampuan guru dalam mengembangkan rencana lanjutan. Hasil analisis dan refleksi tersebut kemudian harus disampaikan pada orang lain dalam bentuk telaah yang diambil dari analisis terhadap kekuatan dan kelemahan rencana dan pelaksanaan pembelajaran yang telah dilakukan. Pendidik berusaha untuk memperbaiki perencanaan dan pelaksanaan pembelajaran agar menghasilkan kualitas pembelajaran yang lebih baik. Untuk 
mengembangkan keahlian ini, pendidik harus memiliki sikap rendah hati mau menerima saran dari orang lain dan melakukan perubahan dalam pembelajaran dengan keinginan untuk terus menerus belajar.

Pendidik memiliki kemampuan untuk berkomuniksasi dengan banyak orang. Kemampuan komunikasi ini terdiri dari kemampuan komunikasi non verbal dan verbal termasuk didalamnya kemampuan untuk berbicara dan menulis dengan jelas, kemampuan menyimak dan menjadi pendengar. Pendidik anak usia dini harus memiliki kemampuan untuk mau mendengarkan anak, orang tua dan bertindak sebagai pendengar aktif yang berarti bahwa pendidik mampu memberikan respon dari apa yang didengar dan berusaha untuk mengambil tindakan bijak sesuai dengan apa yang didengar.

Pendidik anak usia dini harus mampu memimpin timnya (dengan pendidik lain dan orang tua) dan berusaha untuk menunjukkan tanggung jawab. Pendidik bertanggung jawab terhadap apapun yang terjadi selama anak berada dalam proses pembelajaran, memotivasi dan secara langsung memberikan bimbingan pada pendidik atau karyawan yang ada di sekolah. Selain itu, pendidik juga harus memiliki kemampuan untuk mengevaluasi proses dan rencana kegiatan dalam tim tersebut. Kepemimpinan juga terlihat dalam bentuk dapat dipercaya, mampu menjelaskan, memberi dukungan, merespon, menilai, mendengarkan, mengkoordinasi, mampu bekerjasama dan mampu berdiskusi (Edgington, Margaret, 2004).

Pendidik harus memiliki kemampuan untuk bermain penuh dan mampu menciptakan kegiatan belajar yang menyenangkan. Pendidik anak usia dini harus mampu menciptakan kegiatan bermain untuk anak dan mengusahakan kegiatan didapat dari 118 situasi kehidupan yang nyata (kontekstual). Pendidik harus menciptakan lingkungan belajar yang konteksnya bermain baik dalam ruangan atau di luar ruangan. Untuk menciptakan kegiatan belajar yang menyenangkan, pendidik harus berusaha membayangkan dirinya sebagai anak-anak dan bahkan menjadi seperti anak-anak, serta ikut bermain bersama dengan anak.

Pendidik harus memiliki imajinasi dan kreativitas yang tinggi. Untuk menjadi pendidik anak usia dini yang berhasil dan mampu meningkat-kan kegiatan bermain yang menarik dan menyenangkan tidak perlu mengeluarkan uang yang banyak. Pendidik diharapkan dapat menggunakan, memanfaatkan, memaksimalkan material yang ada untuk menciptakan lingkungan yang kaya pada anak. Untuk dapat melakukan hal tersebut pendidik harus memiliki imajinasi dan kreativitas yang tinggi sehingga menghasilkan anak yang kreatif. Keterbukaan pendidik dalam melihat hasil karya dan cara anak memecahkan masalah ketika bermain tanpa tekanan membebaskan anak untuk berimajinasi dan berkreasi. Hal ini berarti bahwa pendidik harus fleksibel dan memandang hasil tersebut sebagai bentuk imajinasi dan kreativitas anak.

Pendidik harus mampu merancang program dan melaksanakan pembelajaran yang mengacu pada analisis kebutuhan anak. Untuk mengembangkan karakteristik ini pendidik harus memahami tahapan setiap aspek perkembangan anak secara utuh, melakukan pengamatan pada anak dan berlatih memahami setiap kebutuhan anak. Program yang dirancang pendidik harus cocok dengan tahapan tersebut. Hal ini berarti program yang direncanakan tidak terlalu tinggi dan tidak pula terlalu rendah dari kemampuan anak. Tema yanag dipilih 
pendidik juga harus sesuai dengan minat anak.

Karakteristik terakhir yaitu kemampuan pendidik untuk secara terus menerus mendokumentasikan serta melakukan penilaian pada perkembangan anak. Pendidik anak usia dini harus mengembangkan dan memiliki tingkat kemampuan yang tinggi untuk mendokumentasikan pelaksanaan pembelajaran baik terhadap perkembangan anak ataupun dalam program. Berbagai bentuk dokumentasi tersebut seperti rekaman pengamatan, hasil belajar, rekaman ilustrasi pengalaman praktek anak, foto, buku, dan video. Tujuan dokumentasi tersebut yaitu untuk melihat bagaimana anak belajar dan apa yang dipelajari anak. Selain itu, dokumentasi tersebut secara praktis dapat dilihat oleh orang tua dan anak, sebagai bahan diskusi untuk diketahui oleh orang tua terkait dengan kemampuan anak yang sering terlihat di rumah dan di sekolah.

Profesionalisme adalah sebutan yang mengacu kepada sikap mental dalam bentuk komitmen dari para anggota suatu profesi untuk senantiasa mewujudkan dan meningkatkan kualitas profesionalnya (Suyanto dan Asep Djihad, 2012). Kualitas profesionalisme seseorang didukung oleh beberapa kompetensi yaitu 1) keinginan untuk selalu menampilkan perilaku yang mendekati standar ideal, 2) selalu meningkatkan dan memelihara citra profesi, 3) senantiasa mengejar kesempatan pengembangan profesional yang dapat meningkatkan dan memperbaiki kualitas pengetahuan dan keterampilannya, 4) mengejar kualitas dan cita-cita dalam profesi (Suyanto, 2012). Oleh karena itu, guru profesional adalah guru yang dapat menjalankan tugasnya secara profesional dan memiliki keinginan untuk terus meningkatkan profesinya dengan banyak belajar untuk menambah pengetahuan terkait dengan profesi yang dijalani. Dengan demikian, profesionalisme pendidik anak usia dini adalah sikap pendidik anak usia dini yang berusaha untuk meningkatkan kemampuannya secara profesional dalam mendidik anak usia dini.

Terkait dengan profesionalisme tersebut, salah satu usaha yang dilakukan untuk meningkatkan kualitas pendidik PAUD adalah dengan memberikan pelatihan-pelatihan atau diklat untuk para guru. Usaha lain yang dilakukan yaitu dengan mengikutsertakan guru pada Pendidikan dan Latihan Profesi Guru (PLPG). PLPG merupakan program yang untuk sementara ini dapat diakui sebagai sarana untuk memberi guru-guru sertifikat sebagai guru PAUD dengan harapan peserta yang lulus PLPG memiliki kompetensi yang lebih baik. Selain itu sikap mental terkait profesionalisme tersebut harus pula ditujukkan oleh guru PAUD dalam bentuk tindakan nyata.

Berikut ini potret profesionalisme pendidik anak usia dini di Yogyakarta. Berdasarkan data yang dijaring penulis secara acak di 5 kabupaten yaitu Bantul, Gunung kidul, Kulon Progo, Sleman, dan DIY, pada sejumlah 100 guru PAUD, diperoleh data bahwa 90 persen guru PAUD memiliki keinginan untuk melanjutkan pendidikan. Sedangkan 10 persen berkeberatan melanjutkan pendidikan di bidang PAUD karena usia yang tidak memungkinkan. Keinginan untuk melanjutkan pendidikan merupakan bentuk keinginan guru untuk meningkatkan kualifikasi akademik yang menjadi salah satu syarat agar pendidik PAUD dapat disebut profesional.

Berdasarkan angket tersebut hampir semua guru PAUD mengisi kegiatan-kegiatan yang terkait dengan pengembangan kompetensi pendidik PAUD yaitu mengikuti kegiatan pelatihan, seminar, membaca bukubuku tentang perkembangan anak dan 
sumber-sumber lain sesuai dengan kebutuhannya dalam mengajar. Ketika pertanyaan angket terkait dengan keikutsertaan guru dalam PLPG, ratarata guru sangat ingin mendapat kesempatan untuk mengikuti PLPG. Guru 90 persen mengisi skala 10 untuk menunjukkan keinginannya mengikuti kegiatan ini dalam skala 1 sampai dengan 10. Adapun alasan guru berdasarkan catatan dalam mengikuti PLPG adalah untuk meningkatkan kompetensi, menambah pengetahuan, dapat diangkat sebagai PNS, dan menguji kompetensi profesional yang dimilikinya sebagai guru PAUD. Antusiasme guru dalam mengikuti PLPG ini terlihat dalam data kasar yang diperoleh penulis dari panitia PLPG UNY, Yogyakarta. Data tersebut disajikan dalam bentuk gambar.

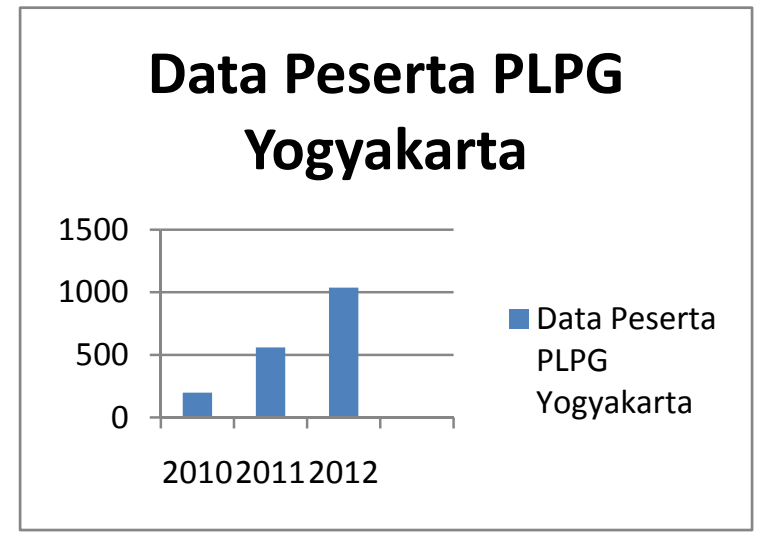

Sumber: Panitia PLPG UNY 2012

Tahun 2010 peserta PLPG sejumlah 197 peserta. Jumlah tersebut meningkat sebanyak 2,84 persen yaitu sejumlah 560 peserta pada tahun 2011. Tahun 2012 meningkat 1,85 persen dari tahun sebelumnya yaitu sejumlah 1036 peserta. Data-data tersebut peningkatan peserta PLPG di Yogyakarta menunjukkan bahwa guru PAUD memiliki keinginan untuk mengembangkan profesinya melalui pendidikan latihan profesi guru dengan kata lain memiliki profesionalisme sebagai pendidik anak usia dini. Namun demikian, data tersebut tidak dapat menunjukkan keinginan perubahan tersebut secara nyata. Banyak dari peserta tersebut yang tidak lulus ketika mengikuti PLPG. Potret ini menunjukkan bahwa kualitas pendidik anak usia dini di Indonesia memang belum baik. Namun usaha-usaha peningkatan tersebut sudah mulai diupayakan oleh pemerintah agar menjadi lebih baik. Untuk itu, profeisonalisme menjadi pendidik anak usia dini harus diusahakan atau ditumbuhkan oleh pendidik PAUD itu sendiri. Meskipun sudah memiliki sertifikat sebagai pendidik PAUD, seorang pendidik harus terus berusaha untuk meningkatkan dirinya sebagai bentuk tanggung jawab yang tinggi terhadap status profesional yang dimiliki. Pengembangan diri pendidik untuk meningkatkan kompetensi kepribadian dan sosial menjadikan pengalaman mengajar berinteraksi dengan anak, orang tua dan masyarakat sebagai cara untuk belajar dan memperbaiki diri, diikuti oleh keinginan untuk terus belajar dari membaca dan memiliki sikap rendah hati untuk mau menerima masukan dari berbagai sumber.

\section{Penutup}

Pendidik anak usia dini diakui sebagai profesi karena untuk menjadi pendidik anak usia dini, seseorang harus berusaha untuk terus menerus mengembangkan profesinya dengan berbagai usaha agar mampu mempertahankan kualitasnya sebagai bagian dari profesi yang profesional. Dengan melihat data-data antusiasme pendidik anak usia dini di Yogyakarta untuk mengikuti PLPG dan data yang diambil secara acak pada 100 orang guru PAUD di Yogyakarta, dapat dikatakan bahwa 90 persen memiliki profesionalisme sebagai pendidik anak usia dini. Walaupun demikian menjadi orang yang profesional perlu melewati proses 
dan masing-masing kompetensi yaitu pedagogik, profesional, sosial dan kepribadian harus senantiasa diuji untuk mempertahankan status tersebut. Pendidik anak usia dini harus mempertahankan profesinya dengan bertanggung jawab melalui usahausaha kreatif untuk terus meningkatkan diri dengan terus menerus belajar.

\section{Daftar Rujukan}

Ahmad Rizali, dkk. 2009. Dari Guru Konvensional Menuju Guru Profesional. Jakarta: PT. Gramedia Widiasarana Indonesia

Anggun Puspita. 2012. 87,3 persen Guru PAUD Tak Penuhi Standar Kompetensi. Diakses dari: http:// www.suaramerdeka.com/ v1/index.php/ read/ news smg/ 2 012/ 05/27/ 119581/873-PersenGuru-PAUD-Tak-PenuhiStandar-Kompetensi, tanggal 25 September 2012, jam 11:41

Brewer, Jo Ann. 2007. Introduction to Early Childhood Education: Preschool through primary grades. USA: Pearson Education, Inc.

Direktorat PAUD. TT. Peraturan menteri Pendidikan Nasional Tentang Standar Pendidikan Anak Usia Dini. Jakarta: Kemendiknas

Driscoll, Amy dan Nagel, Nancy G. 2005. Early Childhood Education, Birth-8. USA: Pearson Education, Inc.

Edgington, Margaret. 2004. The Foundation Stage Teacher in
Action Teaching 3, 4, and 5Year-Olds. London: Paul Chapman Publishing

H.E. Mulyasa. 2012. Manajemen PAUD. Bandung: PT. Remaja Rosdakarya

Kostelnik, Marjorie J, et all. 2007. Developmentally Appropriate Curriculum Best Practices in Early Childhood Education. New J ersey: Pearson Education, Inc.

Direktorat PAUD. 2011. Mengenal Pendidikan Anak Usia Dini di Indonesia. Diakses dari http:// paud.kemdiknas.go.id/in dex.php/home/ bukaLinkBerita $\underline{\mathrm{RSS} / 1}$, tanggal 25 September 2012, jam 11:50

Redaksi. 2012. Kriteria Pendidik Lembaga PAUD. Diakses dari: http:// www.koranpendidikan.co $\mathrm{m} /$ view/ 1268/ kriteria-pendidiklembaga-paud.html, tanggal 25 September 2012, jam 11:46

Rini. 2012. Dirjen PAUDNI: Dorong Guru PAUD Berpendidikan Sarjana. Diakses dari: http:// www.paudni.kemdikbud. go.id/dorong-guru-paudberpendidikan-sarjana/, tanggal 25 September 2012, jam 11:40

Suara Merdeka. 2012. Guru PAUD Belum Penuhi Standar Kompetensi. Diakses dari: http:// www.lazuardibirru.org/g urupencerah/ beritagurupencerah/guru-paudbelum-penuhi-standarkompetensi/, tanggal 25 September 2012, jam 11:44 
Slamet Suyanto. 2005. Dasar-dasar Pendidikan Anak Usia Dini. Yogyakarta: Hikayat Publishing

Suyanto dan Asep Djihad. 2012. Bagaimana Menjadi Calon Guru dan Guru Profesional. Yogyakarta: Multi Presindo. 